\title{
DESIGNING 'TOURIST VILLAGE - PASIRMULYA' WEBSITE THROUGH TRANSFER KNOWLEDGE \& TECHNOLOGY
}

\author{
Hagung Kuntjara SW ${ }^{1 *}$, Anzaludin Samsinga Perbangsa ${ }^{2}$, Retno Dewanti ${ }^{3}$ \\ Bina Nusantara University, Jakarta, Indonesia 11480 \\ *hwijasa@binus.edu
}

\begin{abstract}
Pasirmulya Village, Banjaran District, Bandung Regency, West Java, is geographically located on the slopes of Mount Puntang. Pasirmulya Village has a lot of potential as a thematic tourist destination, such as; Best plantations and coffee products in the world, Tourist sites heritage radio transmitters in the Dutch colonial era, Cycling tracks and cross-country trail motorbikes, Natural tourism and beautiful panoramas, Cultural arts and life of the agrarian Sundanese indigenous people who are relatively still awake, Centers of handicrafts and typical village food, and Homestay Village Wangun. Pasirmulya village with all its uniqueness is very potential to build as an alternative tourist destination, because it is very close to the city of Bandung. The results of field research to record the potential of Pasirmulya village which is grouped into several categories which will be used as web content in page menus according to the categories of potential existing tourism objects. Throughout the collecting data's of potential villages and a long the process of designing the website Tourist Village pasirmulya' also involves the human resources of the local community as an activites guidance of transformation knowledge and technology. It is hoped that this website will also help introduce the Tourist Village - Pasirmulya' to the wider community.
\end{abstract}

Keywords: Tourist village, website

\section{INTRODUCTION}

Bandung Regency - Regional Governments are actively encouraging the emergence of 'Tourism Villages' in an effort to increase economic income and participation of rural communities. This is expected to be able to create new jobs in the village and reduce the amount of urbanization of working village youth in the city. The concept of 'Tourism Village' also allows transformation and increased access to knowledge through rural areas. Total agrarian ecosystems and agrarian culture of the villagers do not need to be changed. Total, only readiness and adjustment is needed to welcome tourists and openness of the community as 'Host of Tourism Village' which is ready to welcome tourists to come or stay touring in the village.

Tourist Village - Pasirmulya, Banjaran District, Bandung Regency, West Java, has a lot of potential as a thematic tourism destination. There are mountain panoramic tourist spots, the best coffee producers, campgrounds, Tourist Village Homestay - Wangun, etc. All of these are hidden potentials that have not been maximized. Tourist visits occur not in careful planning, so that the number of visits is only incidental to the makeshift recommendations.

This Community Services Program - PPM is looking for solutions to the publication of Ecotourism through the utilization of tourism potential and human resources of the village community by involving student service learning and lecturer assistance as a form of community development with a focus on the publication of the promotion of the potential of Tourist Village - Pasirmulya through integrated social media \& websites.

The Community Services Program - PPM is a forerunner to the creation of official tourism websites in the Roadmap of sustainable PPM, it is expected that the Tourist Village - Pasirmulya will have professional publications \& promotions, managed and developed by the most respected village cadets and self-managed. 


\section{Situation Analysis}

The Tourist Village - Pasirmulya, Banjaran District, Bandung Regency, West Java, is geographically located on the slopes of Puntang Mountain, an area that has a lot of potential as a thematic tourist destination, including the best coffee plantations and products in the world, tourist sites Radio transmitter relics in the Dutch colonial era, cross-country cycling tracks, natural tourism and beautiful panoramas, cultural and life art of the agrarian Sundanese indigenous peoples are relatively well maintained, handicraft centers and special food, and one of iconic destination is a Tourism Village Homestay - Wangun. All of which are very potential destinations alternative tourism, because it is very close to the city of Bandung.

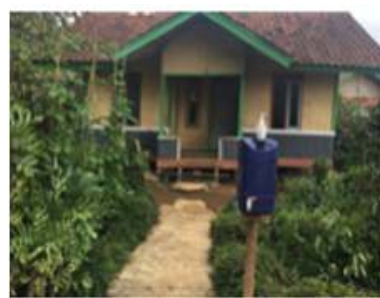

HOMESTAY - DESA WISATA WANGON

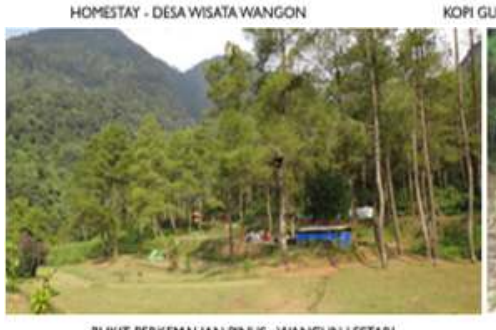

BUKIT PERKEMAHAN PNUS . WANGUN LESTAR

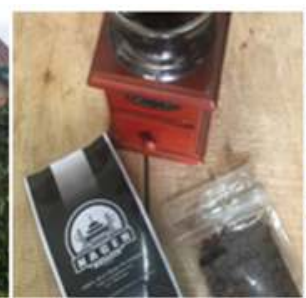

ROPGLNUNG PUNTANG

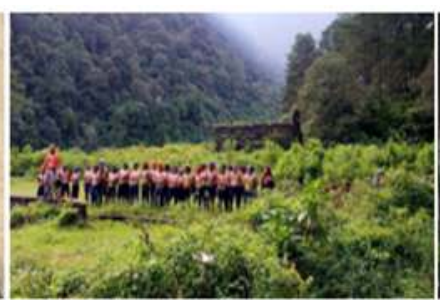

STUS RADIO TERTUA - AMAN KOLONUL

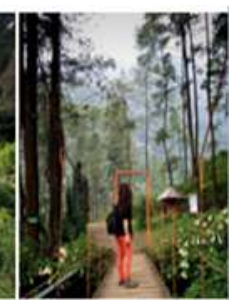

Spor WEaseale

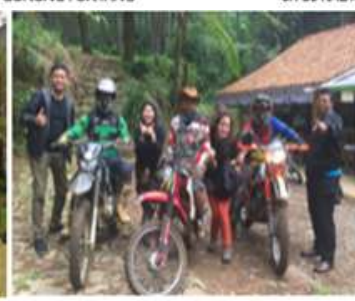

TRACK. JALUR MISATA DESA

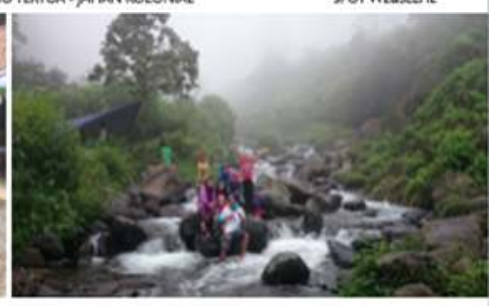

WSATA GUNUNG HABTAT ELANG A UUTUNG JAWA

Figure 1. Potential clusters thematic tourism destination, Source: writer

Until now the potential of the Tourist Village - Pasirmulya is not publicized and unknown to the public. When we browse the internet with the keyword 'Wangon Village', 'Gunung Puntang', Pasir Pasir Mulya Village ', information on the tourism potential above is very limited and the information has not been able to make an interesting picture and encourage people's desire to travel there.

\section{Problem Identified}

The Tourist Village - Pasirmulya needs publication in a planned and integrated communication strategy format to promote its potential as a thematic tourist destination, so that tourism enthusiasts get a good information easily and create a desire to visit it as a form of tourism with a different sensation of experience. The unavailability of this publication is due to the unavailability of human resources who hae concern, un-skills and poor understanding of promotion and branding, as well as commitment and consistency in creating good and sustainable publications to support the existence of a good and integrated Tourism Village potential publication.

\section{Extensive Solution \& Target}

In the digital era and massive social media, the flow of communication has become very heavy and information is very easy to disseminate, technology allows all information to be held. The community will automatically be grouped and interconnected in communities with the same preferences and interests, among them will share information and experience organically, giving and receiving and sharing information as long as it is interesting for the public.

Content is the King - interesting and useful information for the public, will continue to be of interest and shared. In this situation, there will be several leaders for peer of groups who are considered as experts or most experienced by the community, where to ask questions and sources of information, which are very influential and trusted by the group. Each group or individual entity follows, at each time they exchange roles into sources - recipients - information successors. 
Almost all entities become brands in the form of products - services, companies, communities, individuals, etc. like a necessity to use the social media information path, to always be connected or engage with the target continuously. This media is 'shocking' information is easily spread or shared because it is liquid and open. If an entity is not there, it is almost certain that it does not exist and will not be known to the public. The ease of finding or finding on social media becomes a crucial factor that is very important, social media engagement is a guide to the main source of information, namely the website as a landing page for all information publications.

This PPM is an initiative participation that aims to create a form of publication of all the potentials of the Tourist Village - Pasirmulya to be exposed and have high search engine optimization (SEO) information that is easily searchable by the public. Through the integrated social media platform Tourism Village - Wangon is promoted, its existence is raised to be exposed by the public.

This PPM program involved by:

1. Village Government

As the main source of data and mapping the potential of the Tourism Village area - , Pasirmulya, Banjaran District, Bandung Regency, West Java

2. Tourism Village Youth Organization - Pasirmulya

Involved as a participant to get story telling training in preparing promotional content $\&$ design of Photography, Video, Design \& Editing content, and prototype website.

3. Binus Lecturer \& Student Volunteers

Following the Development Community Service program from campus, deployed to collect data and make news as well as being a Youth Village \& Youth Mentor in preparing promotional content designs for Social Media $\&$ the Website accompanied by lecturers.

\section{Community Development Program Result}

The most challenging thing is to give understanding to all stakeholders that the Tourist Village - Pasirmulya needs web publication to be known by the public. In the early days it was an attempt to convince the local government to give trust, access to information and support to the community development program PPM could be run there. At the beginning of data collection on tourism potential, we get key information from the local experts and the government and immediately conduct field research to ascertain whether the reality has the carrying capacity if it will be made into a tour package offer.

Because this program is only run within a period of 4 months with limited funds, we formulated the target achievements until; potential data collection, determined the local human resources training according to needs, designed the website prototype and confirmed whether it was in accordance with the needs. We hope this program is as an initial program that will be carried out sustainably with better funding so that it can involve more communities and academics and make an active and updated Website with the up-date information of tourism conditions. 


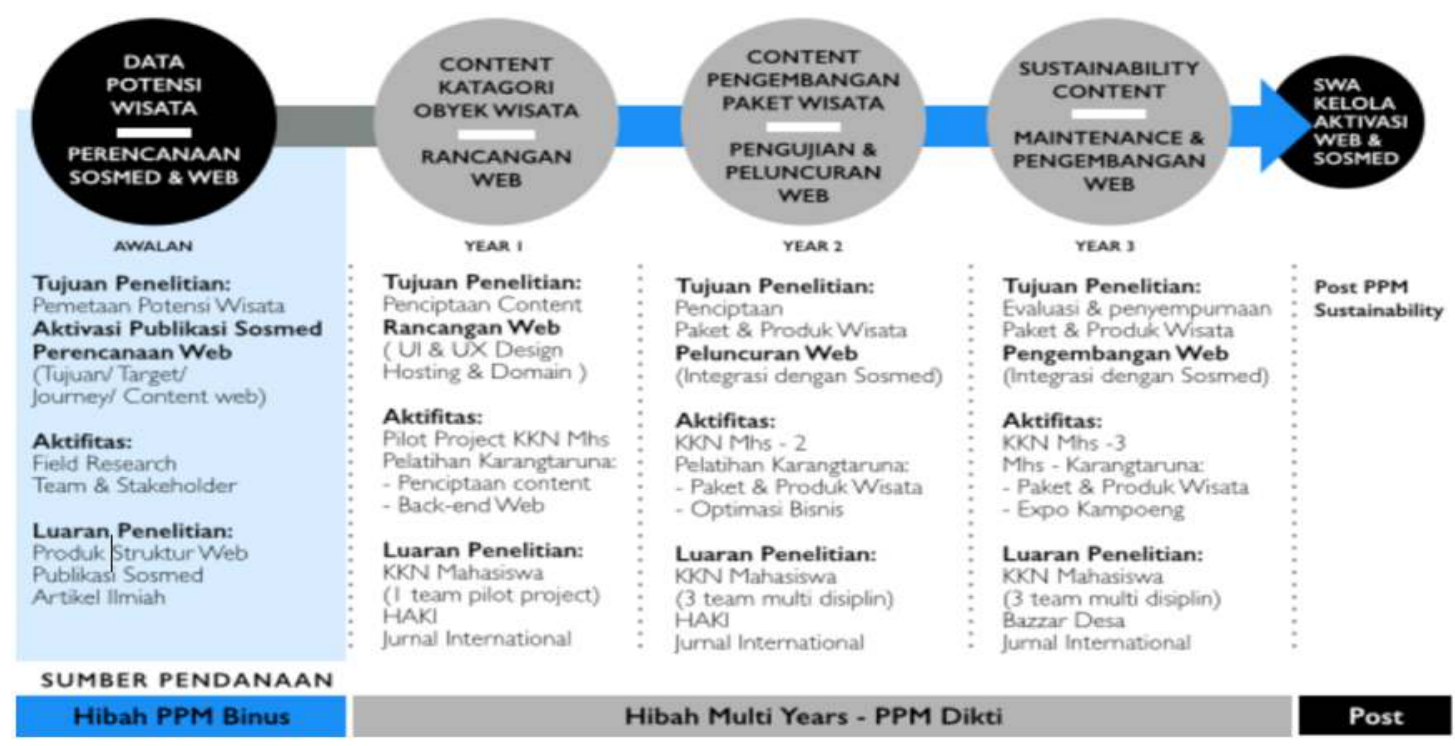

Figure 2. Website Plan Fishbone Diagram - Multiyear Community Development Program We are focus on the $1^{\text {st }}$ stages program, Source: writer

Apac Travel Dashboard - A Look Back At Recent Trends wrote that wherever travelers go, they're online. Whether planning a trip, navigating a new city, or sharing vacation memories, they turn to the web, using whatever device is at hand. (Apac). This reference further convinced us that this tour website creation program is very important. We carry out data analysis and formulate together the clustering of tourism packages that serve as a vacation option within a certain period or tour without staying. Among the tour packages offered are; Stay at Wangun Homestay, Pine Hill Wangun Lestari Campsite, Puntang Coffee Plantation Tour, Stop at Haben Nagen Coffee Café, Historycal site Malabar $1^{\text {st }}$ Station Radio in Java (Dutch colonial era), Tour around the village with Motortrail or bicycling, River path Nature tours, Local Culinary Tours \& Souveneer, Agricultural Shopping Tours, as well as several potential household industries including; Silver crafts, the center of the shoes and clothing industry.

We create the design of the website prototype based on the formula of the tourism clusters and filled it with temporary information to get an overview of the web prototype. Consideration of the flow of information as a visitor journey is implemented in the Web User Interface, both accessed using a computer or mobile. Obviously the target viewer will get interesting sequential information. 


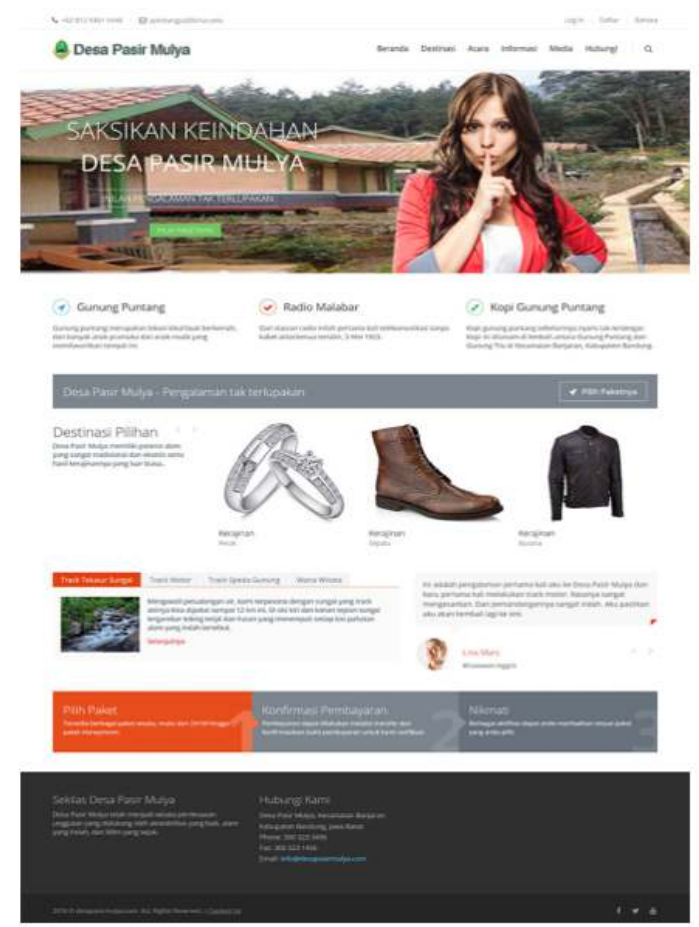

Figure 3. Web Prototype; Tourist Village - Pasirmulya, Source: writer

Web like home building, content is the activities that live in the building. We focus on training young people, to be able to create interesting story content both in photos, videos, or news that supports tourism. This training is to foster an understanding of what issues are interesting for outsiders to stop and travel in their village.

They get training in photographing, processing the results of shots and discussing ideas that are relevant to the needs of web content. This training process is directly carried out during a visit to Pasirmulya or remote villages through remote assignments and the results are discussions through the internet, this is to familiarize them to experience communication with internet use. All of this is just basic training as an experience to be improved as an experienced content maker, web admin who can answer all the interactions that come in and update content regularly, programmers behind the next web development with certain sub-themes, and the final objective is the website will auto maintain by local recources. It will expected that in the long run, this training can be continued more intensively and involves community development programs carried out by students with supervision and guidance from lecturers, so that they can learn from each other and fuse the gap as village and city boys.

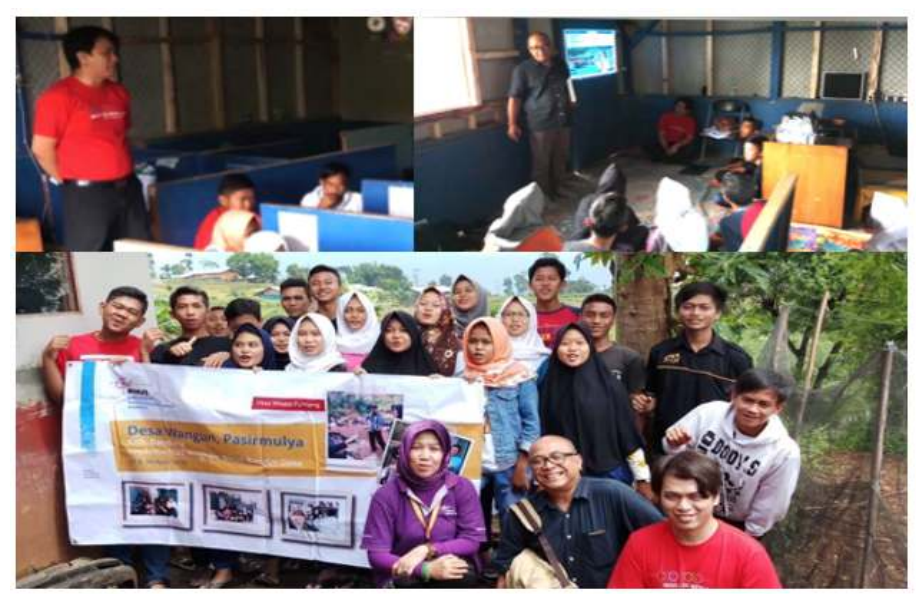

Figure 4. Training Web Content; Young Resources - Pasirmulya, Source: writer 


\section{CONCLUSION}

Problem-Solving Participative in the concept of 'Tourist Village - Pasirmulya' is transforming and increasing access to knowledge through remote villages, Suppressing the amount of urbanization $\&$ living in the village is also a viable and even proud choice, The ecosystem and agrarian culture of rural communities is sustainable \& renewable. Openness of the community as 'Host of Tourism Village' who are ready to welcome tourists.

The village of Pasirmulya still needs the development of facilities and infrastructure, as well as the readiness of the mindset of its citizens as a tourist host. The website is an out and inward information facility, coming out introducing the potential of Pasirmulya tourism village, into the citizens can know themselves and their environment, develop the potential to actively participate in supporting the creation of tourism villages that improve the lives of citizens.

The most important and fundamental is that villages can develop like cities, if opportunities and access to information and transportation can be penetrated. Being a tourist village does not need to change the village into a new face that loses its original character, precisely the original uniqueness of the village that will invite people to come. The original is preserved and the new ones are studied and developed according to the local context.

\section{REFERENCES}

Apac Travel Dashboard - A Look Back At Recent Trends. https://apac.thinkwithgoogle.com

Oktavianti, E., \& Hakim, L. (2013). Etnobotani Pekarangan Rumah Inap (Homestay) di Desa Wisata Tambaksari, Purwodadi, Pasuruan, Jawa Timur. Journal of Indonesian Tourism and Development Studies, 1(1), 39-45.

Sutrisno, B.(2018). Profil BKM Desa Pasirmulya Kecamatan Banjaran Kabupaten Bandung Jawa Barat :

http://www.academia.edu/7624621/Profil_BKM_Desa_Pasirmulya_Kecamatan_Banjaran_Ka bupaten_Bandung_Jawa_Barat

Wheeler, A. (2009). Designing brand identity. John Wiley \& Sons,. 